日本オペレーションズ・リサーチ学会論文誌

Journal of the Operations Research

Society of Japan

Vol. 19, No. 4, December, 1976

\title{
都市政策効果の分析モデルの開発
}

(株)日立製作所システム開発研究所 北嶋弘行・佐々木良一

\section{A DYNAMIC MODEL TO ANALYZE THE REPERCUSSIONS OF URBAN POLICIES}

\author{
HIROYUKI KITAJIMA and RYOICHI SASAKI \\ Systems Development Laboratory, Hitachi, Ltd.
}

(Received July 14, 1975; Revised October 12, 1976)

\begin{abstract}
As the interactions among urban activities have increased and complicated, it is urgently demanded to analyze the effects which might be caused by urban policies. The aim of this model is to analyze not only direct effects but also repercussions of urban policies upon citizens' welfare and to assist decision-makers in evaluating policy alternatives and in detecting urban problems in advance. One of the new ideas in this model is that urban activities are grasped from two principal viewpoints of system theory (feedback and hierarchy), and the simulation model is formulated on the basis of this framework.

(1) feedback system; Urban activities can be considered as such a feedback system as to maximize citizens' utility (output) by satisfying various demands of citizens(in put) with equipment or services(process). Herein exist two main feedback loops, one is administrative control and the other is the influence of the benefit level on the demand pattern.

(2) hierarchical system; Urban activities can be considered as a hierarchical system. From the hierarchical points of view, urban activities were categorized into four levels and the relationships between a higher level and a lower level are identified. The method used to build the simulation model was System Dynamics and the method applied to analyze and formulate urban activities was Scenario. Some of model parameters which are highly sociological and psychological were defined on the result of the enquete investigation for administrative officials of Hiroshima city.

Concerning Hiroshima city, the long range simulation (20years) was carried out on this model with regard to several alternative urban policies.
\end{abstract}

\section{1. はじめに}

今日，都市に㧤いては多くの問題が発生し，しかもそれらは深刻の度合を深めつつある。都市問題 の解決を困難にしている原因の一つ炑，都市の諸活動間には錯綜した相互関連性が存在するため，都 市施策は直接的効果のみならず正負の波及効果を伴うことにある。すなわち，都市問題の解決のため には，問題相互間の関連性を分析・把握したうえで都市問題全体としての解決を図る方法が必要であ る。本報告は，都市機能間の相互関連性をモデル化することになり，都市施策の波及効果の分析用具 として役立てることを目的としたものである。ここでは, 先ず, 都市機能間の相互関連性をモデル化 するのに用いた方法を示し, 次にこの方法を用いて開発した都市施策の効果分析モデルの構成执よび 広島市を例とするンミュレーンョン結果を述へる。本内容は, 昭和 46 年度から 3 年間行った「都市 
経営ンステムの研究」の一部である。

\section{2. 都市機能のモデル化の目的}

本研究の目的を明らかにするために, 都市経営ンステムに扮ける本研究の位置づけを述へる。都市 経営ンステムは行政体のトップ層の意志決定をサポートすることを目的とした情報ンステムであり， その中核をなすンステムモデルは図1のように構成される。このうち本研究が対象とするのは効果分 析モデルの部分である。効果分析モデルの機能は，行政施策が住民福祉に与えるであるう効果を，都 市のサービス水準を表す物理的指標で予測することである。価值モデルでは。都市サービス指標を住 民効用に変換するとともに住民効用の目標值からの乘離を出力する。行政モデルでは，住民効用の目 標值からの乘離を行政需要に変換する。この部分では, 都市活動の大規模・複雑性を考慮して, 最適 制御を行う方法よりも，むしろ意志決定者とモデルとの会話形式によって適応的・学習的な制御を行 う方向をとった。

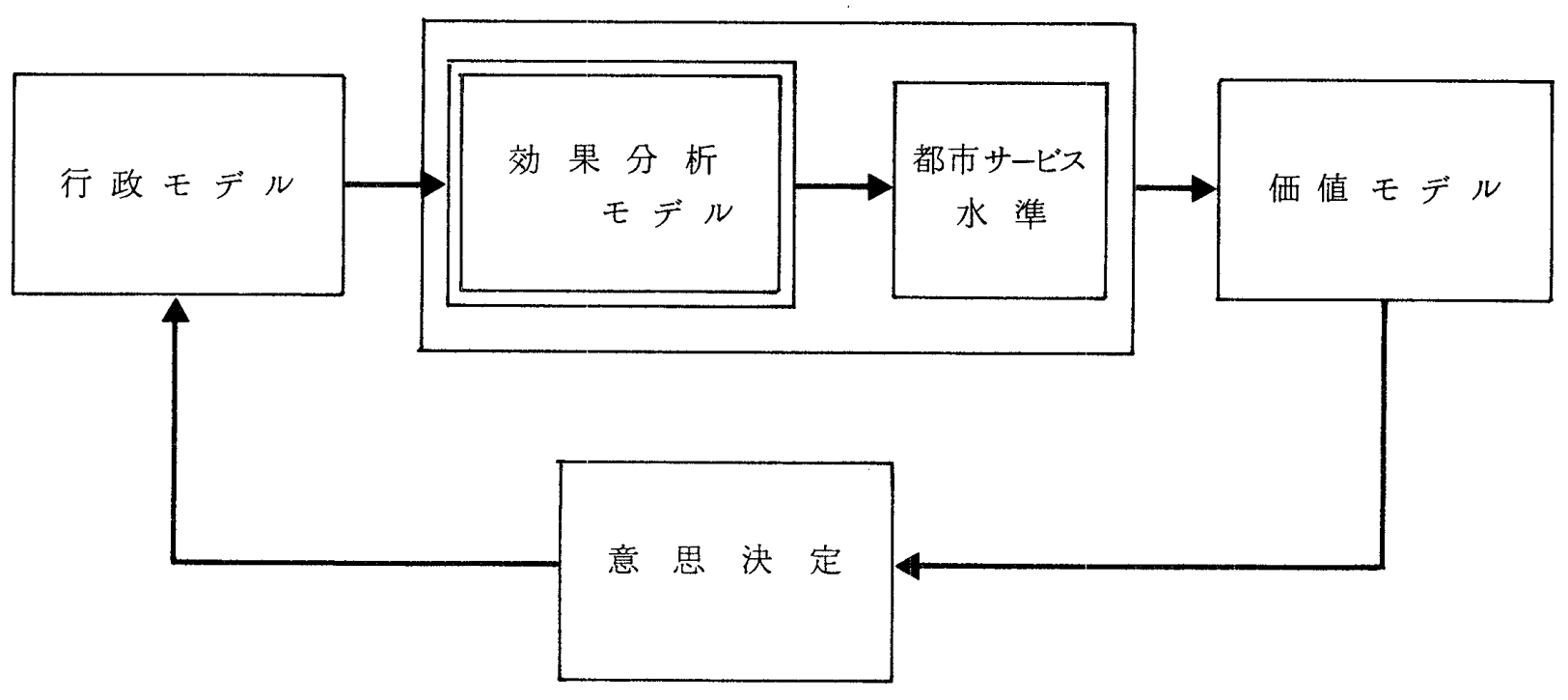

図 1 効果分析モデルの位置づけ

\section{3. 都市機能のモデル化の方法}

都市活動は，多くの計量困難な要素が錯綜しており不確定的にしか説明されない。このような対象 を扱う手法は, ソフト・テクノロジーとしていくつか開発されてきている。これらは大別して, 準定量的方法 とンミュレーション法とに分けられる。準定量的方法は, 直観的な情報の組織化には適しているがここから 定量的な情報を抽き出すことは難かしい。一方, シミュレーション法は, 現象の定量的な取り扱いが可能で あるが。その反面, 対象を構造化し数式体系に構成するのに工夫を要する。ここでは両者を組み合わせて， 夫々の長所を活かしながらモデルを作成することとした。具体的にはンステム・ダイナミックス（以下 $\mathrm{S}$ D と略）法の動態的変化，非線形性の取り扱いが可能である点に着目し，これを基本的手法とした。 さらに，SD法を補うものとして，対象の因果関係の分析の段階にンナリオ法を併用した。 


\section{$3 \cdot 1$ 都市機能の定性分析}

都市の諸活動間の因果関係を分析する目的でンナリオを展開した。行政施策のインパクトは，先ず 直接に対応する都市活動領域に変化をもたらし。その結果が他の領域に波及効果をむたらすと考えら れるのでンナリオは次の 2 段階で展開した。

(1)分野毎のシナリオ……都市活動を, 経済, 社会, 教育, 保健などの 13 分野に分割し, 分野単位 に「広島市基本計画書」等の関連資料に基きンナリオを作成した。

(2)分野間のンナリオ……分野間のンナリオをつき合わせて，分野間の関連についてのンナリオを作 成した。分析はメンバー内の討議や関連資料の調査に基きマトリックス形式で行った。

\section{$3 ・ 2$ 都市機能のシステム論的モデル化}

都市機能の因果関係の分析結果から，都市機能はンステム論の観点から，フィードバック拉よび階 層性の考光方で説明できるものと仮定し，これをモデル作成上の枠組とした。

(1) フィードバック (図 2 )

都市機能は，都市に発生する種々の需要（入力）を，都市の施設やサービス（処理）を用いて充足 し，住民の享受する効用（出力）を最大化する過程であると考える。ここに，2つの主要なフィード バック・ループが存在する。1つは，行政体が住民効用を最大化するための制御機能で，これは公共 施設（処理）にだけでなく，工場排ガスの排出規制のように需要そのものにも働きかける。もう $1 つ$ のループは，住民効用の水準変化が需要パターンに及ほす影響である。これは，道路サービスの向上 がさらに多くの自動車交通量を誘発する現象などに見られるところであるが，都市の制御を一層複雑 にしており，需要そのものの制御が必要とされる理由でもある。

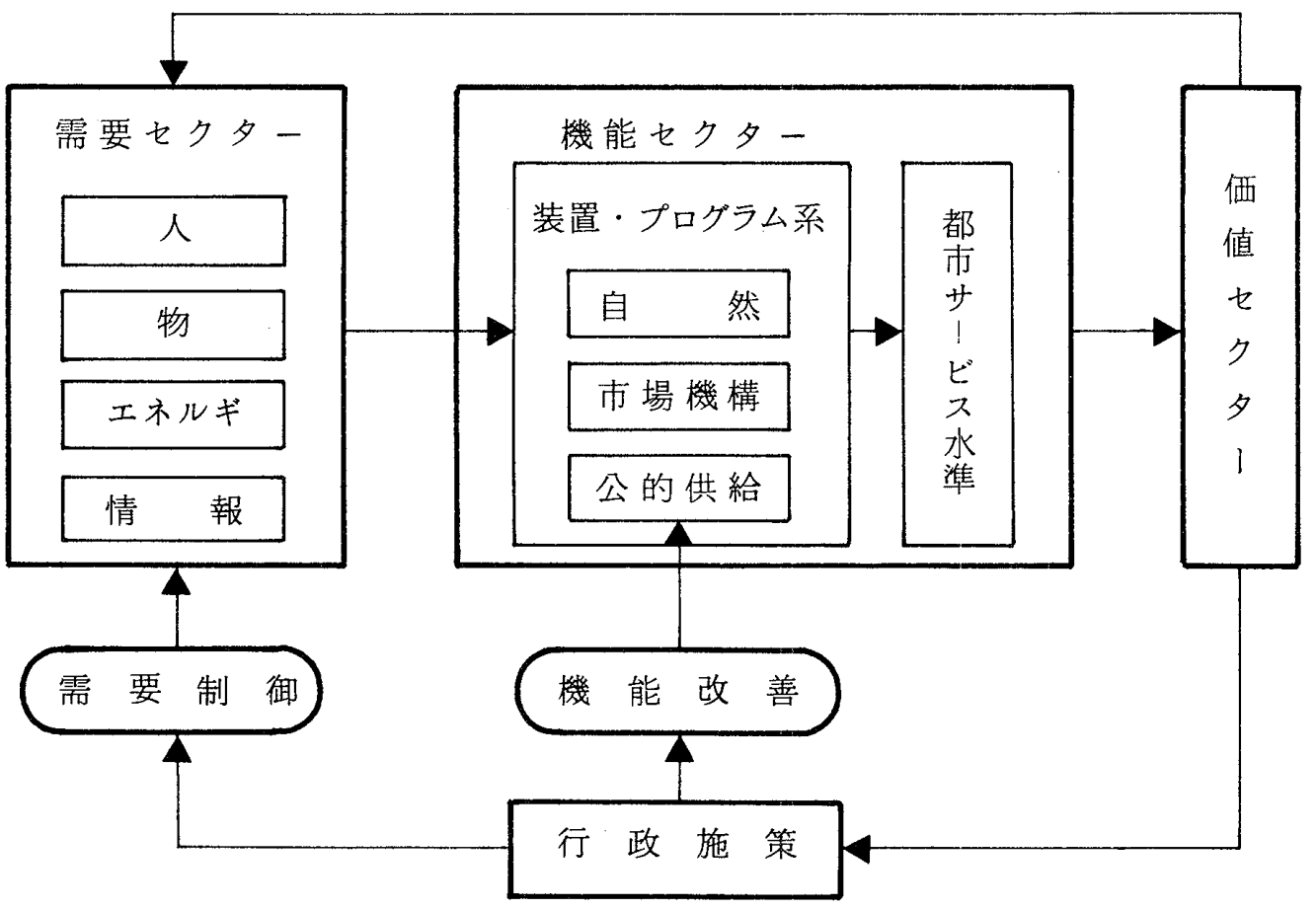

図 2 都市機能のフィードハック的把握 
（2）階層性（図 3 )

都市機能を階層性の立場からみて次のように分類した。都市機能は大別して，人口構成，産業構造 などの都市構造の骨組みをなすマクロ・レベルと，住民の公共財に関するアクティビティの変化を対 象とするミクロ・レベルとに分類する。さらに，ミクロ・レべルの都市機能を，住民にとっての本来 的意味という観点から次の 3 階層に分類する。

(1)生活系……保健。教育，余睱活動などのように住民生活の根源的ニーズに対応する活動。

(2)移動系……人, 物, エネルギ, 情報などの都市活動に必要な資源の輸送, 伝達を行う活動であり, 交通, 物流, エネルギ供給。上下水道, 情報伝達などの活動が含まれる。

(3)環境系……都市活動の過程で発生する排出物の処理を行う活動。

これらの階層間の関系は，上位が下位を一方的に規定するというものではない。階層間は双方向的 関係にあり，上位での変化が下位に及ほす影響の大きさが，逆方向の影響の大きさに比較して大きい という関係にあるものと考えられる。階層間には主に次の 2 つの関係が認められる。

(1)上位での都市活動量の変化に伴って下位の需要量が変化するという関係で, 例えば, 生産活動や 余睱活動の増加に伴う交通需要の増加などの現象が相当する。

(2)下位でのサービス水準の変化に伴って上位での都市活動量が変化するという関係で, 例えば, 交 通サービス水準が生産活動に対して, 産業立地パターン, 輸送コスト, 労働力確保などの面で及 ぼす影響などの現象が相当する。

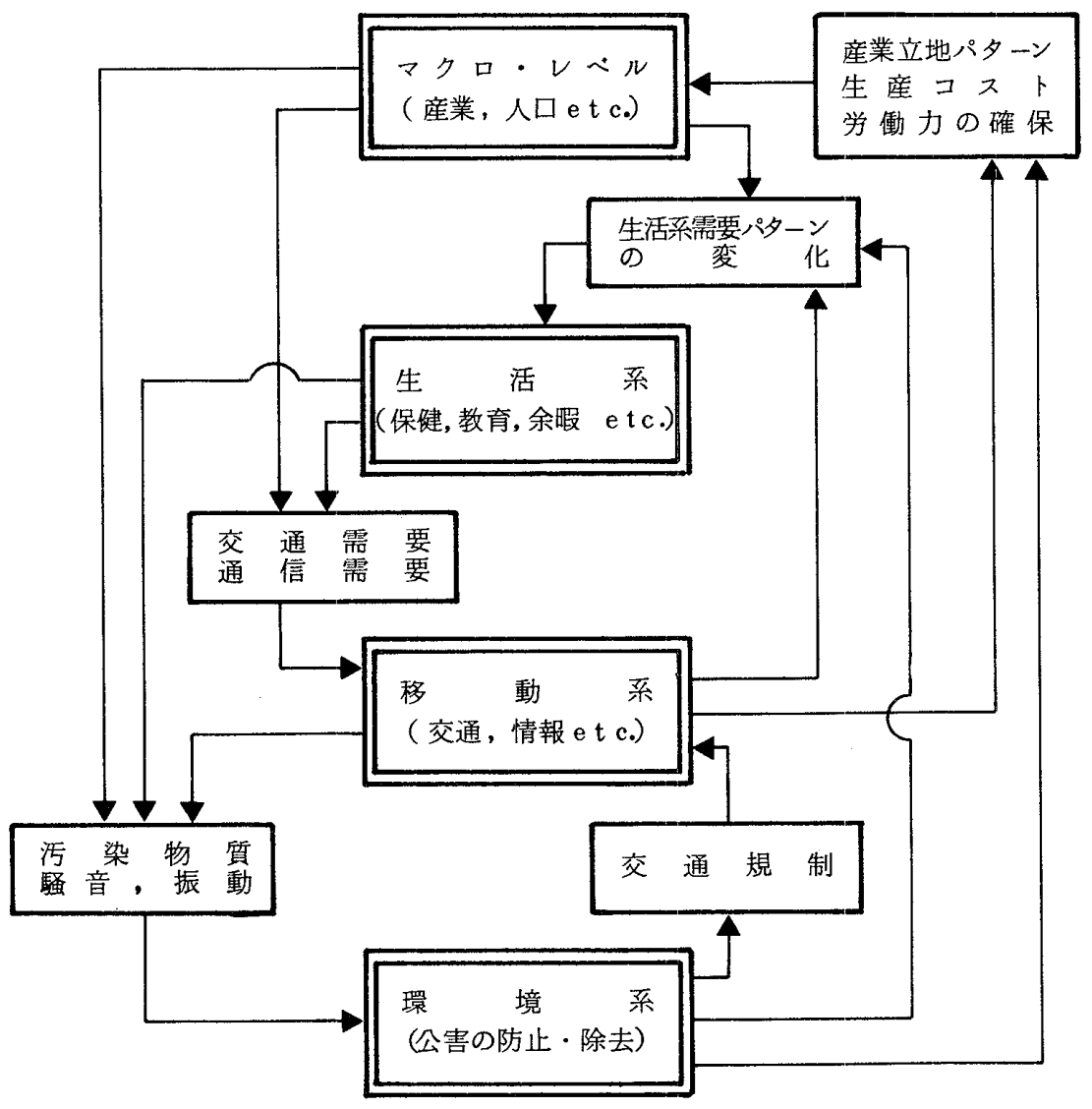

図 3 都市機能の階層的把握 


\section{4. モデルの構 成}

以上に述べたフィードバックと階層性の関係を枠組として, シミュレーンョン・モデルを図 4 のよ うに構成した。モデルは都市機能の階層性に対応して, 大別してマクロモデルとミクロモデルとから 構成し，ミクロモデルをさらに生活系，移動系，環境系のサブモデルに分割した。行政施策が都市节 ービス水準に及ぼす効果は両モデルを次のように連動することによって説明できる。

(1)マクロモデルで行政施策による都市基本構造の変化を説明する。

(2)ミクロモデルでは，変化したマクロレベルの諸変数（人口，事業所数など）と行政施策のインパ クトを入力とし，ミクロレベルの都市活動の変化を説明する。この結果，都市サービス水準を表 す諸指標の值が出力される。

モデルは全てSD言語によって記述し，規模はマクロモデルが約 50 0ステップ， ミクロモデルが約 700 ステップである。以下に各サブモデルの内容を説明する。

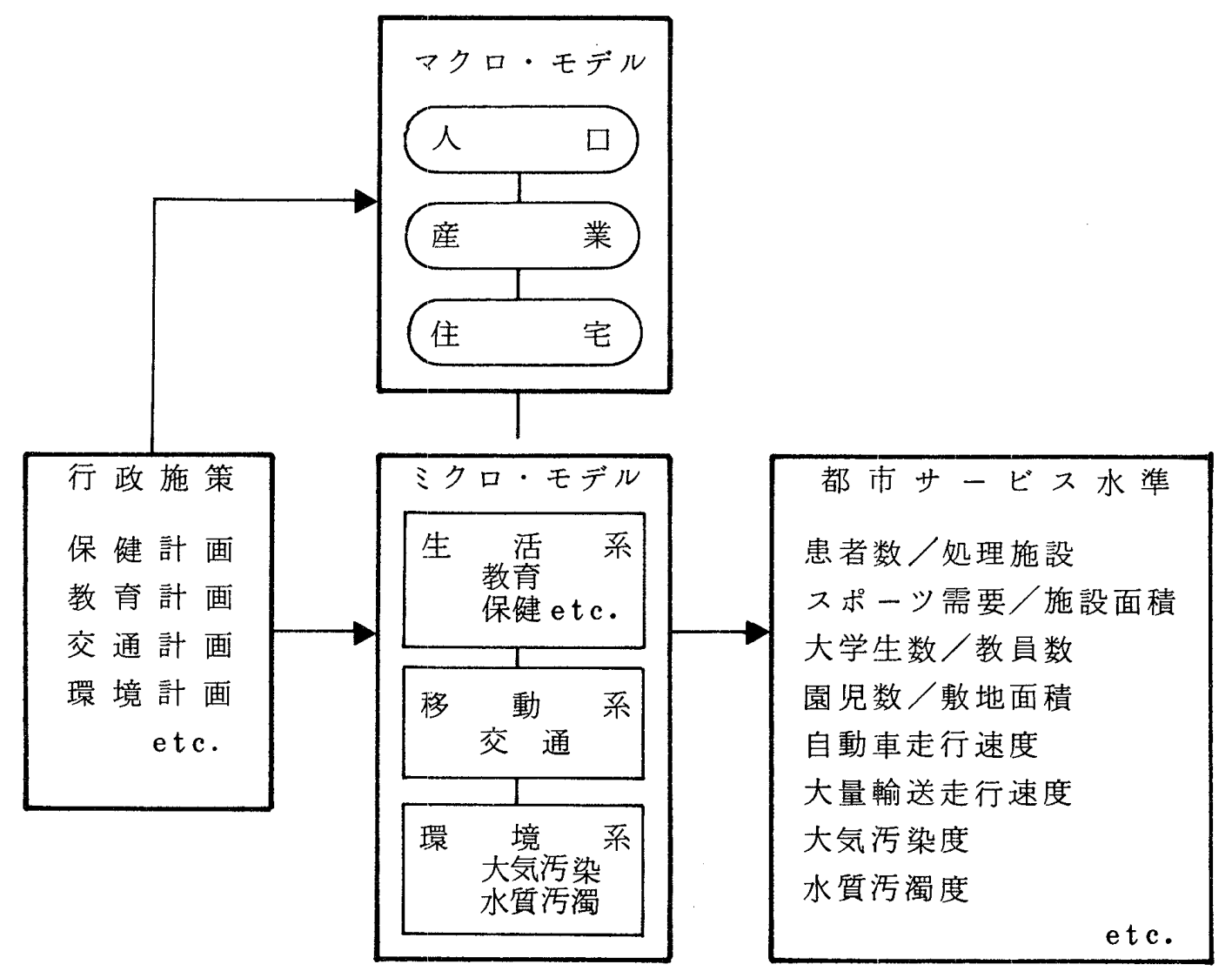

図 4

\section{4 ・ 1 マクロモデル}

人口，産業。住宅，土地の制約などの都市の基本的要因の相互関連をモデル化することによって都 市の構造変化を把えるものである。ここでは，資本都市魅力拉よび住民都市魅力がダイナミックスを 説明するうえでの基軸として用いられている。資本都市魅力とは産業事業所の立地に対する都市の魅 力要因を表し，産業関連の社会資本（道路，鉄道など）によって説明する。住民都市魅力とは，住民 にとっての都市の住み良さの要因を表し，生活関連の社会資本 (教員, 公園など ) によって説明する。 
マクロモデルに扔いて行政施策はこれらの社会資本の操作変数として働きかける。マクロモデルと しては, 都市経営ンステムにて別途開発したモデルを用いた。

$4 \cdot 2$ 生 活 系

都市機能のダイナミックスを説明するうえでの鍵は，需要発生メカニズムにある。ところで，教育， 保健，余㗇活動などの生活系の需要発生は，多くの社会的・心理的要因に支配されて複雑であり，か つ既存の理論や分析の例も少い。ここでは，専門家の持つ直観・経験という主観的情報を組織的に活 用する方法として，需要発生のパラメーターをアンタート調査によって設定するという試みを行った。 アンケート調査の枠組は。生活系の需要量の変化を被説明変数とし，これの説明変数としてフィート゚ バック括よび階層性の仮定にしたがって。マクロレベルの変数招よびミクロレベルの都市サーピス水 準を設定した。アンケートは説明変数の被説明変数に対する寄与率を調査対象とし，回答方法は促進

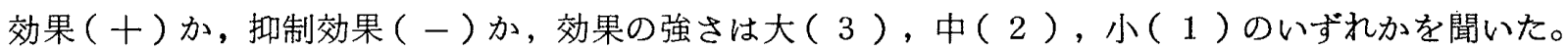
設問数は, 説明変数 $\left(\begin{array}{ll}3 & 2\end{array}\right) \times$ 被説明変数 $\left(\begin{array}{ll}1 & 7\end{array}\right)$ である。調査対象者は広島市行政担当者の方々と し, 回答者数は各設問毎に 10 名とした。回答結果の単純平均值の一部を表 1 亿示す。調査結果は $\mathrm{S}$ Dモデルで次の形式で用いた。

$$
\begin{aligned}
& \omega_{i}=\sum_{j=1, N} \alpha_{j i} \times P_{j} \\
& \omega_{i} ; \quad \text { 生活系需要 } i \text { の発生に関する魅力度 } \\
& P_{j} ; \quad \text { 説明変数 } j \text { の值 } \\
& \alpha_{j i} ;
\end{aligned}
$$

\begin{tabular}{|c|c|c|c|c|c|c|}
\hline \multicolumn{3}{|c|}{ 説明変数 } & $\begin{array}{l}\text { 文 } \\
\text { 华 } \\
\text { 活 の } \\
\text { 動増 } \\
\text { 需加 } \\
\text { 要 } \\
\end{array}$ & $\begin{array}{l}\text { 大 } \\
\text { 学 } \\
\text { 進の } \\
\text { 学増 } \\
\text { 需加 } \\
\text { 要 }\end{array}$ & $\begin{array}{l}\text { 医 } \\
\text { 療 } \\
\text { 需増 } \\
\text { 加 } \\
\text { 要 }\end{array}$ & $\begin{array}{l}\text { 公 } \\
\text { 園 } \\
\text { の } \\
\text { 利增 } \\
\text { 用加 } \\
\text { 者 }\end{array}$ \\
\hline \multirow{3}{*}{$\begin{array}{l}\text { Z } \\
\text { 变 } \\
\text { 变 } \\
\end{array}$} & 余 暇 時 & 間 の 增 大 & 2.4 & 0.5 & 0.2 & 2.2 \\
\hline & 所 得 水 & 準 の 向上 & 2.1 & 2. 4 & 1.5 & 1. 3 \\
\hline & 老人 人 & 口の 增 加 & 1.6 & 0.0 & 2.5 & 1.5 \\
\hline \multirow{5}{*}{$\begin{array}{c}\text { 都 } \\
\text { 市 } \\
\text { サ } \\
\text { l } \\
\text { ビ } \\
\text { ス } \\
\text { 水 } \\
\text { 準 }\end{array}$} & 文 化 活 & 動 の 充 実 & 2.6 & 0.7 & 0.2 & 0.9 \\
\hline & 大 学 教 & 育 の 充 実 & 1.0 & 2.5 & 0.7 & 0.5 \\
\hline & 医 療 機 & 関 の 充 実 & 0.2 & 0.3 & 1. 4 & 0.2 \\
\hline & 交 通 $の$ & 便 が 向 上 & 1.1 & 0.3 & 0.3 & 1.1 \\
\hline & ゴミ処理・ & 下水処理の向上 & 0.0 & 0.0 & -0.4 & 0.4 \\
\hline
\end{tabular}

表 1 アンケート調查結果 (一部) 


\section{$4 \cdot 3$ 移 動 系 (交通)}

モデルでは規模の制約から, 都市問題としての深刻さ, 括よび他活動との相互関連の強さに着目し て交通のみを扱った。モデルの枠組を図 5 に示す。他活動との関連については階層性の考え方を用い た。すなわち, 上位レベルとの関連については, 交通需要の発生をマクロレベル(就業者数, 人口) 扣よび生活系需要量で説明し, 一方, 交通サービス水準が生産活動就よび生活系需要量に及ぼす影響 を考慮した。下位レベルとの関連については, 排気ガスが環境系に与える影響を考慮し，一方，環境 系に招ける大気污染が自動車保有率拉よび機関選択に及活す効果を考慮した。交通の枠内については フィードバックの考光方を用いてモデル化を行った。交通需要として大量輸送機関（以下M $\mathrm{T}$ と略） 利用トリップと自家用車利用トリップを設定し, 夫々のサービス指標として走行速度, 混雑度。コスト 等を設定する。処理施設として道路，MTを設定し, 行政施策はこれらの処理施設に対して, 道路総 面積，M T 容量，MTと自動車の走行速度比，料金などの形で作用するすのとしてモデル化した。フ 1ードバック。ループとしては。M T 招よび自動車のサービス水準が，機関分担という形で夫々の需 要量に及ほす影響を考慮した。本モデル意思決定者との会話型での利用法を意図しているので，モデ ル内では行政体の意思決定は外生化し，したがって，サービス水準から行政施策へのフィードバック ・ループは扱わなかった。パラメータは既存の分析結果や統計を参考に設定した。

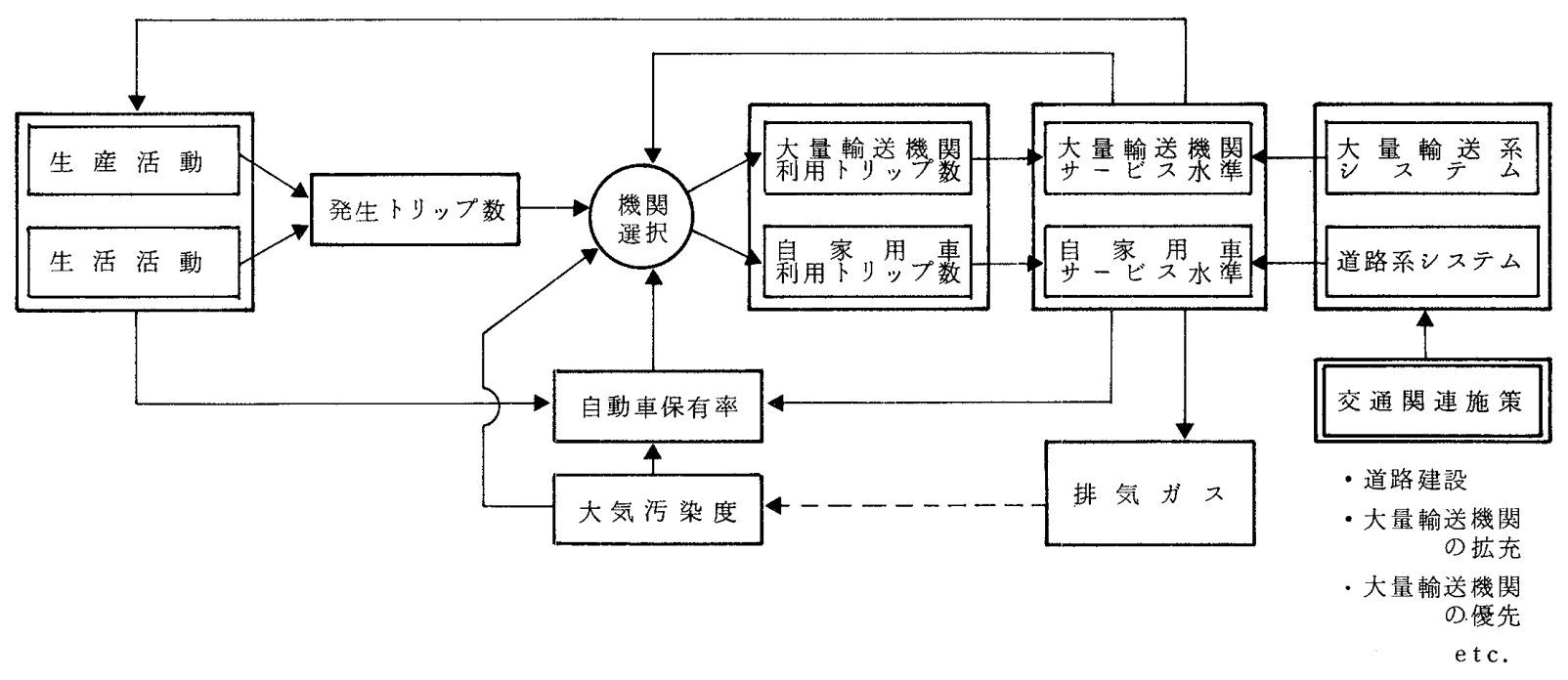

図 5 移動系 (交通) モデルの枠組

\section{$4 \cdot 4$ 環 境 系}

環境污染のうち広島市に括いて住民の重視度が高い大気污染と水質污濁をモデル化した。環境系は 図6に示すように。大別して污染プロセス（需要，処理に対応）とそれに対する住民反応プロセス(価 值に対応）によって把握した。污染プロセスは次の 3 段階で把握した。(1)污染物質の発生（パイ煙や 污水の排出），(2)污染物質の拡散（大気污染，水質污濁）。(3)生態系の挩乱（緑の袈失，奇形魚の発 生）,このうち(3)については生態系への影響を定量的に把握することが困難なので明示的に扱うこと を断念した。住民反応プロセスは，次の 3 段階で把握した。(1)環境污染の認識，(2)環境に対する住民 
の不満度増大，(3)住民パワーの形成。環境污染に対して市の行政施策は次の方面から働きかけるすの としてモデル化した。(1)環境改善施設（下水道など）の建設，(2)排出規準の強化，(3)排出源（工場な ど）の流入規制。環境系の枠内に括けるフィードバック。ループとしては，住民パワ一の形成が企業 の污染発生の自主規制に及ぼす影響を考慮した。他の都市活動との関連については階層性の考え方を 用いた。上位レベルとの関連については, 污染物質の発生をマクロレベル（人口，製造業数），移動 系 (自動車総走行距離) で説明し, 一方, 環境污染が生活系の需要パターン招よび移動系 ( 自動車保 有率拈よび機関選好）に及ほすす効果を考慮した。

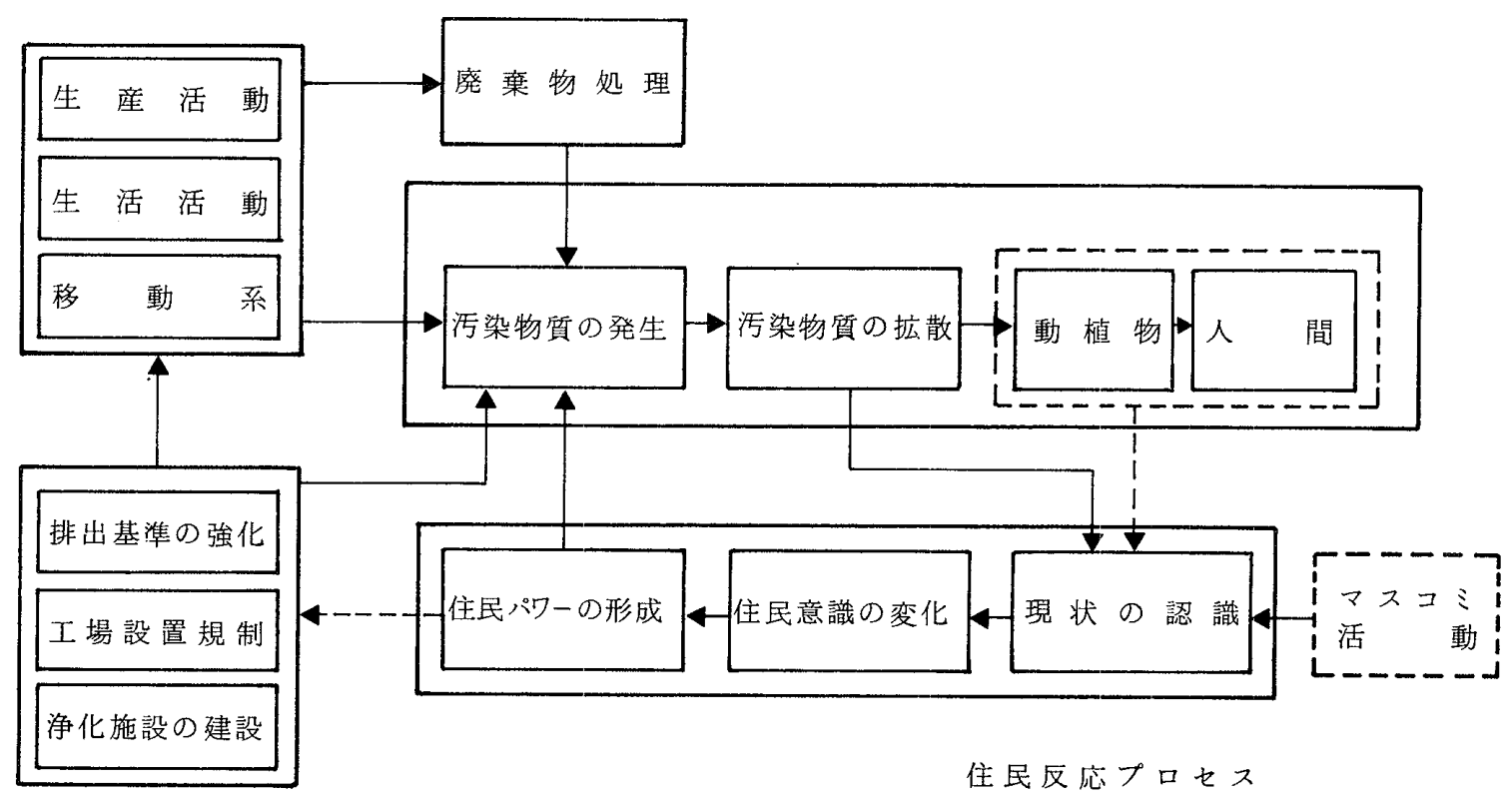

行 政 施 策

図 6 環境系モデルの枠組

\section{5. シミュレーション結果}

以上に述べたモデルによるンミュレーンョン結果を概説する。対象地域は広島都市圈（広島市括よ び周辺11町村）とした。ンミュレーンョンの期間は, 本モデルが戦略的なレベルでの意思決定を対象 とすることから 20 年間の長期間とした。シミュレーンョンは幾通りかのケースについて行った。設定 したケースは，広島市の基本計画などから判断して予想される場合（標準ケース； $\mathrm{S}$ 略），拉よび これを基準として特定部門に重点的に公共投資を行った場合 (生活優先, 産業優先, 大量輸送機関の 強化, 道路交通の強化, の 4 ケース) である。ケース Sの場合の出力の一部を図 7 亿示す。 


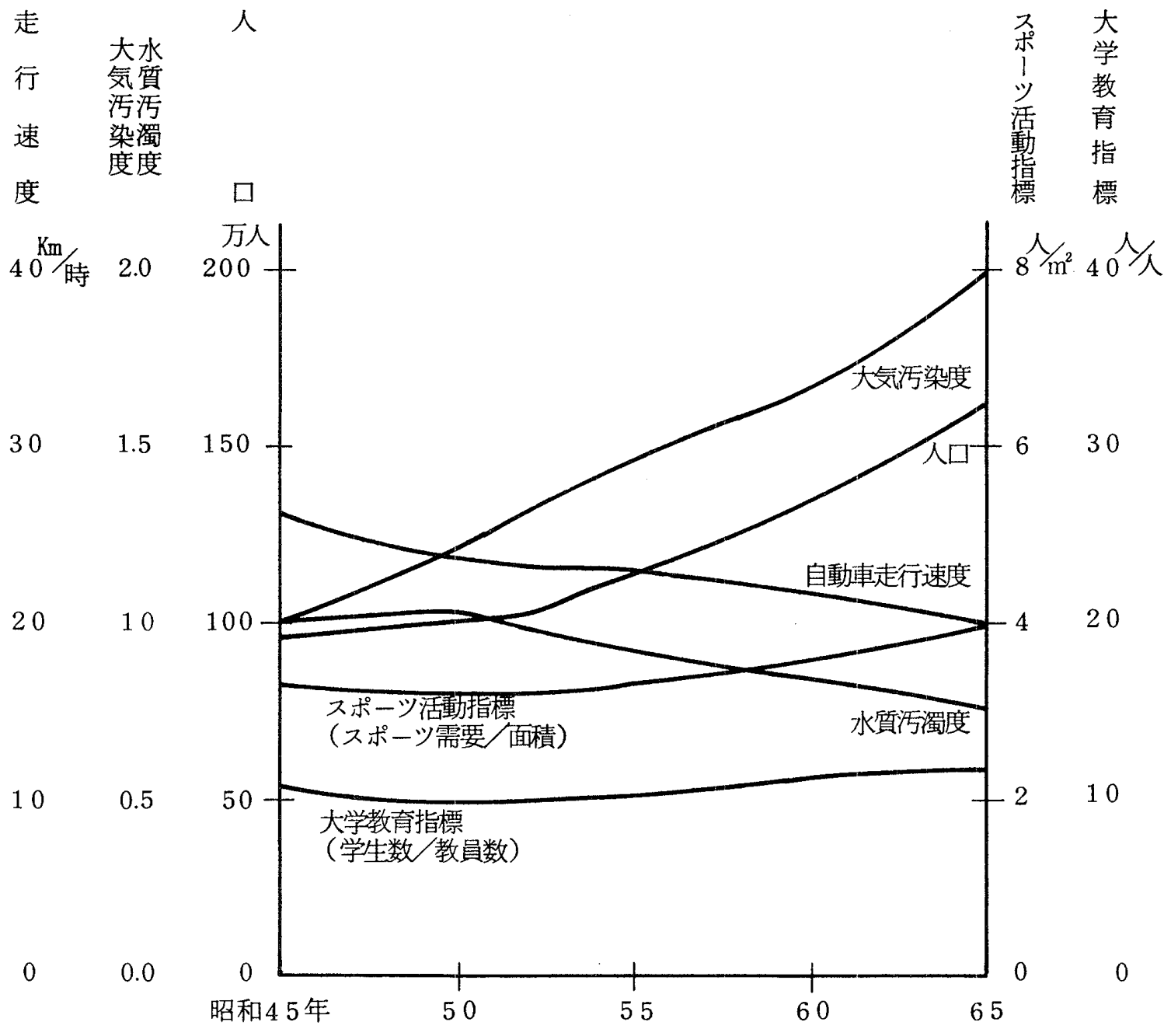

因 7 シミュレーンョン結果( 標準ケース)

ケース $\mathrm{S}$ と他のケースとの比較を容易するために, 昭和65年時点での予測値の比較を表 3 に示す。 また。各ケースで用いた政策変数のリストは表 2 の通りである。以下に，Sケースと他ケースとの比 較を表 3 にしたがって若干述べる。 
表 2 政策変数リス卜

\begin{tabular}{|c|c|c|c|c|c|c|}
\hline 変 & 標準 ケース(S) & 他ケースでの手段 & $\begin{array}{l}\text { 生 } \\
\text { 活 } \\
\text { 優 } \\
\text { 先 }\end{array}$ & $\begin{array}{l}\text { 彦 } \\
\text { 業 } \\
\text { の } \\
\text { 優 } \\
\text { 先 }\end{array}$ & $\begin{array}{l}\text { 大 } \\
\text { 量 } \\
\text { 輸 } \\
\text { 送 }\end{array}$ & $\begin{array}{l}\text { 道 } \\
\text { 路 } \\
\text { 交 } \\
\text { 通 }\end{array}$ \\
\hline スポーツ施設面積 & 前年比 $\quad 1.035$ & 前年比 $\quad 1.07$ & 0 & & & \\
\hline 文化活動施設面積 & 前年比 & 前年比 $\quad 1.08$ & 0 & & & \\
\hline 保育所 - 幼稚園の面皘 & 1.035 & 前年比 & $\mathrm{O}$ & & & \\
\hline 大学の教員 数 & 前年比 & 前年比 & 0 & & & \\
\hline 病院処理可能件数 & 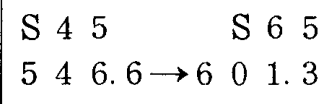 & 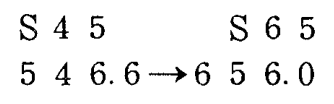 & 0 & & & \\
\hline 下水道普及率 & 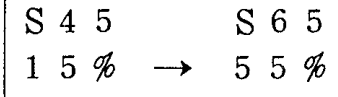 & $\begin{array}{l}\text { S } 45 \\
15 \% \rightarrow \quad \text { S } 65 \\
95 \%\end{array}$ & $\mathrm{O}$ & & & \\
\hline 消防 - 警察官数 & 前年比 & 前年比 $\quad 1.08$ & 0 & & & \\
\hline 道 路 面 積 & $\begin{array}{cc}\text { 前年比 } & \\
\text { 市内 } & 1.0 \\
\text { 郊外 } & 1.07\end{array}$ & $\begin{array}{lll}\text { 前年比 } & & \\
\text { 市内 } & 1.04 \\
\text { 郊外 } & 1.14\end{array}$ & & 0 & & 0 \\
\hline 岸 壁 総 延 長 & 前年比 & 前年比 & & 0 & & \\
\hline 鉄道貨物取扱量 & 前年比 $\quad 1.04$ & 前年比 & & 0 & & \\
\hline ハス／自動車速度比 & $\begin{array}{r}\mathrm{S} 45 \\
0.7 \rightarrow \quad\end{array} \quad \begin{array}{r}\mathrm{S} 65 \\
0.7\end{array}$ & 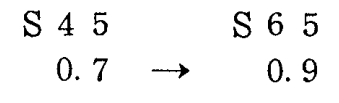 & & 0 & $\mathrm{O}$ & \\
\hline 大量輸送容量 & $\begin{array}{l}\text { S } 45 \\
93.5 \rightarrow \quad \text { S } 65 \\
20\end{array}$ & $\begin{array}{l}\text { S } 45 \\
93.5 \rightarrow \quad\end{array} \quad \begin{array}{l}\text { S } 65 \\
43.6\end{array}$ & & 0 & 0 & \\
\hline 公 園 面 積 & $\begin{array}{lll}\text { 市内 } & \text { 前年比 } 1.05 \\
\text { 郊外 } & 50 \rightarrow 340\end{array}$ & $\begin{array}{ll}\text { 市内 } & \text { 前年比 } 1.1 \\
\text { 郊外 } & 50 \rightarrow 620\end{array}$ & 0 & & & \\
\hline
\end{tabular}


表 3 各ケースのンミュレーンョン結果

（ S.65 時点での標準ケースとの比較）

\begin{tabular}{|c|c|c|c|c|}
\hline ケ - ス & $\begin{array}{l}\text { 生 } \\
\text { 活 } \\
\text { 優 } \\
\text { 先 }\end{array}$ & $\begin{array}{l}\text { 産 } \\
\text { 業 } \\
\text { 優 } \\
\text { 先 }\end{array}$ & $\begin{array}{l}\text { 大 } \\
\text { 量 } \\
\text { 輸 } \\
\text { 送 } \\
\text { の } \\
\text { 強 } \\
\text { 化 }\end{array}$ & $\begin{array}{l}\text { 道 } \\
\text { 路 } \\
\text { 通 } \\
\text { の } \\
\text { 強 } \\
\text { 化 }\end{array}$ \\
\hline 総 人 $口$ （人） & $+7.0 \%$ & $+8.5 \%$ & $+6.7 \%$ & $-\quad 3.0 \%$ \\
\hline 製 造 業 （事業所数） & +1.0 & +1.4 & +2.2 & -1.5 \\
\hline 建 設 業 （事業所数） & +14.5 & +74.3 & +14.2 & +41.4 \\
\hline 第 3 次 産 業 （事業所数） & +2.0 & $+\quad 3.0$ & +13.0 & -17.0 \\
\hline スポーツ需要量 & +29.0 & +10.9 & +6.7 & +2.9 \\
\hline 文化活動需要量 & +27.7 & +13.5 & $+\quad 7.9$ & +4.3 \\
\hline 就学前教育需要量 & +14.5 & +14.2 & +8.2 & $+\quad 3.5$ \\
\hline 大学教育需要量 & +24.0 & $+\quad 9.3$ & +5.3 & $+\quad 0.2$ \\
\hline 自動車交通 量 $\quad($ トリップ) & +13.4 & +7.7 & $-\quad 5.7$ & $-\quad 3.4$ \\
\hline 大量輸送トリップ数 (トリップ) & +13.0 & +15.0 & +21.0 & $+\quad 3.0$ \\
\hline 大気污染量 & +11.0 & +8.0 & -4.0 & -2.0 \\
\hline 水質污濁量 & -31.0 & +6.0 & +2.0 & -1.0 \\
\hline スポーツ活動サービス水準 $\mathrm{m}^{2}$ 久。回 & +51.5 & -10.0 & -6.5 & -3.0 \\
\hline 文化活動サービス水準 $\left(m^{2} /\right.$ 人回 $)$ & +66.7 & $-\quad 3.8$ & -7.4 & $-\quad 3.8$ \\
\hline 就学前教育サービス水準 $\left(\mathrm{m}^{2} / 人\right)$ & +60.0 & 0.0 & -1.0 & $+\quad 1.0$ \\
\hline 大学教育サービス水準 (人/人) & +30.0 & $-\quad 4.8$ & $-\quad 3.8$ & 0.0 \\
\hline 大量輸送混雑度 (人/台) & +13.0 & -46.0 & -43.0 & $+\quad 3.0$ \\
\hline 大量輸送速度 & -14.0 & +65.0 & +57.0 & +70.0 \\
\hline 自 動 車 速 度 & -14.0 & +65.0 & +5.0 & +69.0 \\
\hline
\end{tabular}


(1) 生活優先政策

生活系の公共施設に重点を置いた場合で, 当然, 生活系のサービス水準が向上し, 1 人当りの生活 系活動量も増大する。しかし, これに伴って人口流入が増加（ $\mathrm{S} の 7 \%$ 増）し, その結果, 大気污染 中交通泳滞が増加する。（ $\mathrm{S}$ と比較して, 大気污染量は $11.0 \%$ 増, 自動車走行速度は $14.0 \%$ 減）。こ れ、生活優先政策をとる場合にも，人口流入という要因について配慮しておくことの必要性を示唆し ている。

(2) 産業優先政策

産業関連の公共投資に重点を置いた場合には，人口が $\mathrm{S}$ と比較して $8.5 \%$ 増加し，このため生活系 のサービス水準が低下することが予想される。また人口や産業の拡大に伴って環境悪化が進行し，S と比較して大気污染量は $7.8 \%$ 増, 水質污濁量は 5.7 \%増となることが予想される。

（3）大量輸送機関の強化

モデルでは大量輸送容量执よびバス／自動車速度比を増加する形で扱っている。この場合には大量 輸送のサービス水準が向上し，そのため自動車から大量輸送への乗り換えが生じ，大気污染や道路溜 帯が緩和することが予想される。（ $\mathrm{S}$ と比較して自動車速度は $5.0 \%$ 増）この結果，人口や産業が拡 大し（ $S$ と比較して人口は 6.7 \%増，第 3 次産業事業所数は $13.0 \%$ 増）,生活系サービス水準はやや 低下することが予想される。

（4）道路交通の強化

道路建設に重点を置いた場合，交通のサービス水準が著しく向上する（ S と比較して自動車走行速 度は 70.0 \% 増)にもかかわらず，人口はむしろ減少することが予想される。これは道路面積の増加 は土地の不足を招き地価を高騰させ，その結果，人口や産業の流入が抑制されるためと解釈できる。 自動車と大量輸送機関との関連についてみると, 道路の走行速度の増大に伴。て路面の大量輸送機関 の走行速度む向上し, この結果, 利用者の選好度はむしろ大量輸送機関の方に傾くことが予想される。 （ S と比較して，自動車利用者は $3.4 \%$ 減，大量輸送機関利用者は $3.0 \%$ 增）

\section{6. おわりに}

本研究で対象とした都市機能のようにil1-structured な対象についてS D法を適用する利点 は，予測のッールとしてよりも，岂しろ時間軸上での分析を通して対象の特性や今後に予想される問 題を理解するこ亡にあると考劣る。今後は意思決定の場での適用を通じて都市機能の分析ツールとし て充実を図りたい。

本研究を行うにあたり，地方行政ンス広研究所拉よび広島市役所 荒田誠之助氏ならびに上皇輝彦 氏に終始甚大なご協力をえたことを付記し，深く感謝の意を表したい。

\section{参 考 文 献}

[1] Coleman, J., Introduction to Mathematical Sociology, The Free Press of Glencoe, London, 1964. 
[2] 淛作所ンステム開発研究所, 都市総合管理ンステムの研究開発報告晝 $(1)$, 都市経営ン ステム・モデルの開発に関する研究，(財)地方行政ンステム研究所, 1973 .

[3] House, Po, The Urban Environmental System, SAGE Publications, Inc., Beverly Hills, 1973 .

[4]飯尾要, 経済サイバネティクス, 日本評論社, 1972 .

[5]アイザード,W., ライデル，C．P. 著, 川嶋辰彦訳, 社会ンステムに挌ける一般均衡論, 情報社会科学講座, 学研, 1972 .

[6] Masser, I., Analytical Models for Urban and Regional Planning, David \& Charles Ltd., Newton Abbod, 1972.

[7]村上泰亮, 熊谷尚夫, 公文俊平, 経済体制, 岩波書店, 1973 .

［8]田村明也。現代都市政策壮 都市の装置, 岩波書店, 1973 。

[9] Parsons, T., Smelser, N. J., Economy and Society, Routledge \& Kegan Paul Ltd., London, 1956. 